\title{
Heterozygosity and fitness in a threatened songbird: blood parasite infection is explained by single-locus but not genome-wide effects
}

\author{
Justyna Kubacka ${ }^{1}$ (D) Edyta Podmokła ${ }^{2}$ (D) Judith Korb ${ }^{3}$ (D) Anna Dubiec ${ }^{1}$ (D)
}

Received: 22 August 2019 / Revised: 27 January 2020 / Accepted: 3 February 2020 / Published online: 5 March 2020

(c) The Author(s) 2020

\begin{abstract}
In non-pedigreed populations, insights into effects of inbreeding can be obtained by correlations between individual heterozygosity and fitness-related traits (HFCs). Using an information-theoretic approach, we explored whether heterozygosity of microsatellite markers, measured as internal relatedness (IR), is associated with infection by blood parasites (Plasmodium, Trypanosoma, or Leucocytozoon) in the threatened Aquatic Warbler (Acrocephalus paludicola). We also explored whether any of the markers is more influential than others, or than IR, in explaining blood parasitism (single-locus effects). While we observed that IR was a relatively important predictor of Plasmodium parasitism, we did not find strong evidence for IR to correlate with infection by the identified blood parasites, accounting for sex and population effects. Therefore, our data did not support negative inbreeding effects on blood parasite infection in the Aquatic Warbler. However, we found singlelocus effects, such that individuals heterozygous at AW-03 and Ase19 had lower probability of infection by blood parasites pooled together and by Plasmodium, respectively. This indicates that these two markers are in linkage disequilibrium with unknown fitness loci which are related to resisting or clearing blood parasites, and which confer a heterozygote advantage in the Aquatic Warbler. Our results add to the growing evidence that single-locus effects contribute more to HFCs than formerly recognized and have implications for Aquatic Warbler conservation.
\end{abstract}

Keywords Heterozygosity-fitness correlations · General effects · Local effects · Plasmodium · Trypanosoma · Aquatic Warbler

\section{Zusammenfassung}

Heterozygosität und Fitness bei einem bedrohten Singvogel: Blutparasitenbefall wird durch Einzel-Lokus, aber nicht durch Genom-weite Effekte erklärt

Für Populationen, für die keine Informationen zu Abstammungsverhältnissen vorliegen, können Einblicke über Inzuchteffekte durch Korrelationen zwischen individueller Heterozygosität und dem Auftreten Fitness-relevanter Merkmale (,heterozygosity-fitness-correlations“; HFCs) gewonnen werden. Für den bedrohten Seggenrohrsänger (Acrocephalus paludicola) untersuchten wir, ob Heterozygosität in Mikrosatelliten Markern, gemessen als interne Verwandtschaft (,,internal relatedness“; IR), mit der Befall durch Blutparasiten (Plasmodium, Trypanosoma oder Leucocytozoon) korreliert, in dem wir einen Informationstheoretischen Ansatz wählten. Wir untersuchten ebenfalls, ob irgendeiner der Marker einen größeren Einfluss hat als andere Marker, oder als IR, um den Befall mit Blutparasiten zu erklären (Einzel-Lokus Effekt). Während wir beobachteten, dass IR ein relativ wichtiger Prädiktor für Parasitenbefall mit Plasmodium ist, fanden wir keinen

Communicated by M. Wink.

Electronic supplementary material The online version of this article (https://doi.org/10.1007/s10336-020-01753-0) contains supplementary material, which is available to authorized users.

Justyna Kubacka

jkubacka@miiz.waw.pl

1 Museum and Institute of Zoology, Polish Academy of Sciences, Wilcza 64, 00-679 Warsaw, Poland
2 Department of Comparative Anatomy, Institute of Zoology and Biomedical Research, Jagiellonian University, Kraków, Poland

3 Evolutionary Biology and Ecology, University of Freiburg, Freiburg, Germany 
starken Hinweis darauf, dass IR mit Infektion durch die identifizierten Blutparasiten korreliert, wobei wir Geschlecht und Populationseffekte berücksichtigten. Daher unterstützen unsere Daten nicht die Hypothese eines negativen Einflusses von Inzucht auf den Befall mit Blutparasiten im Seggenrohrsänger. Wir fanden jedoch Einzel-Lokus Effekte. Individuen, die am AW-03 Lokus heterozygot waren, hatten eine geringere Wahrscheinlichkeit generell mit Blutparasiten befallen zu sein, während Heterozygosität am Lokus Ase19 negativ mit Plasmodium-Befall korrelierte. Dies deutet daraufhin, dass diese beiden Marker im Kopplungsungleichgewicht mit unbekannten Fitness-relevanten Loki stehen, die mit der Resistenz oder dem Beseitigen von Blutparasiten einhergehen und die einen Heterozygoten-Vorteil beim Seggenrohrsänger bewirken. Unsere Ergebnisse tragen bei zu der wachsenden Erkenntnis, dass Einzel-Lokus Effekte stärker als HCFs sein können und sie haben Auswirkungen für den Schutz des Seggenrohrsängers.

\section{Introduction}

Heterozygosity and fitness correlations (HFCs) relate individual genetic variation to traits associated with fitness, giving insight into inbreeding depression and population viability (Reed and Frankham 2003; Grueber et al. 2008). HFCs have been found for survival, clutch size, breeding success, growth rates, and parasite infestation (Coltman et al. 1999; Rowe et al. 1999; Slate et al. 2000; Townsend et al. 2009; White et al. 2015; Cézilly et al. 2016). HFC research allows for a better understanding of evolutionary ecology of a species and can support its conservation (Grueber et al. 2008).

HFCs have been studied using molecular markers, such as microsatellites. They arise due to genome-wide effects (the general effect hypothesis) and/or single-locus effects (the local effect hypothesis) (Hansson and Westerberg 2002). General effects are observed when the heterozygosities of functional and marker (i.e., neutral) loci are associated (identity disequilibrium, ID), as they both respond in a similar way to inbreeding. Thus, if fitness is impaired by the lowered heterozygosity of genes, there is a correlation between fitness and marker heterozygosity. For example, in the Soay Sheep (Ovis aries), microsatellite heterozygosity was inversely correlated to parasitism by gastrointestinal nematodes and mortality caused by these parasites (Coltman et al. 1999). Local effects are found when the heterozygosity of a marker locus is related to that of a fitness-associated locus (linkage disequilibrium, LD), for instance due to physical linkage (Szulkin et al. 2010). The neutral marker hitchhikes with the selected locus and influences the heterozygosity metric more than do other markers under study. For example, heterozygosity at a single microsatellite locus predicted whether tuberculosis was localized or spread in the body of Wild Boars (Sus scrofa) (Amos and AcevedoWhitehouse 2009).

HFCs have been used to study inbreeding especially in animal populations, which lack information on pedigrees to calculate the individual coefficient of inbreeding $(F) . F$ defines the probability that two alleles at a locus are identical by descent. In HFC studies on non-pedigreed populations, the underlying assumption is that $F$ is inversely related to heterozygosity at a number of molecular markers (multi-locus heterozygosity, MLH). This assumption has been subject to debate. On the one hand, the association between MLH and $F$ was found to be weak when a low number of markers were used (Balloux et al. 2004; Slate et al. 2004). However, a more recent study (Forstmeier et al. 2012) made an important point that there is discrepancy between $F$ calculated using a pedigree and the realized identity by descent, IBD (which determines the true rate of inbreeding), due to random events in Mendelian segregation. This discrepancy, rather than insufficient marker number, could explain the weak relationship between $F$ and MLH. The strength of this relationship is also determined by variance in inbreeding, marker polymorphism, and the level of IBD (Hansson and Westerberg 2002; Csilléry et al. 2006; Ljungqvist et al. 2010; Taylor et al. 2010; Forstmeier et al. 2012). Overall, the literature shows that even at a modest number (e.g., up to 11), microsatellite markers can reliably detect HFCs that are attributable to inbreeding (Rowe et al. 1999; Slate et al. 2000; Hansson et al. 2004; Seddon et al. 2004; Forstmeier et al. 2012). To ensure legitimate inferences, it is important to test whether the markers of choice indicate inbreeding and whether there is variance in inbreeding, and to distinguish between the general and the local effects (Balloux et al. 2004; Pemberton 2004; David et al. 2007; Szulkin et al. 2010).

An important trait associated with fitness is resistance to parasites (Hamilton and Zuk 1982; Morand and Poulin 2000; Marzal 2012). In birds, some of the key parasites are vector-transmitted protozoans that invade the bloodstream. These include mainly the intra-erythrocytic hematozoans of the genera Plasmodium, Haemoproteus, and Leucocytozoon, and the extracellular kinetoplastid of the genus Trypanosoma (Atkinson and Van Riper III 1991; Zídková et al. 2012). The fitness costs of blood parasitism are mediated by extensive damage in a variety of tissues, including destruction of erythrocytes, and activation of the immune system (Molyneux et al. 1983; Atkinson and Van Riper III 1991; Valkiūnas 2005). Infection with Plasmodium, the agent of avian malaria, negatively correlates with hatching success, brood provisioning rates, and fledging success (Knowles et al. 2010), survival (Stone et al. 1971; Beier et al. 1981; Krama 
et al. 2015; Ilgūnas et al. 2016; Townsend et al. 2018b), predation risk (Møller and Nielsen 2007; Krama et al. 2015), song quality and output (Gilman et al. 2007), and fat score during migration (Shurulinkov et al. 2012). In passerines, experimental medication with anti-malarial drugs showed that hematozoan blood parasites negatively affect clutch size, hatching success, parental provisioning rates, nestling growth, fledging success, and survival (Merino et al. 2000; Marzal et al. 2005; Knowles et al. 2010; Martínez-de La Puente et al. 2010). Infections with trypanosomes have been associated with later arrival to breeding grounds in spring, siring fewer offspring, and less effective nest defence against a predator relative to uninfected individuals (Rätti et al. 1993; Hakkarainen et al. 1998; Dyrcz et al. 2005).

As in birds hemoparasite infection is an important fitness determinant, it is crucial to identify its underlying variables. One of the traits with a potential effect on infection occurrence is the genetic diversity of the host (Amos et al. 2001; Frankham 2005). However, the link between genetic diversity and blood parasitism in birds is not well understood, because studies that addressed it have been scarce and yielded mixed results (MacDougall-Shackleton et al. 2005; Vallender et al. 2012; Boerner et al. 2013; Ferrer et al. 2014; Townsend et al. 2018a). In addition, only one study focused on a species with a small population (Ortego et al. 2007). In species with a small and fragmented population, studying HFCs is crucial, as it can benefit their conservation (Reed and Frankham 2003; Grueber et al. 2008).

Here, using an information-theoretic approach, we investigated whether the probability of infection with vector-transmitted blood parasites is predicted by (1) host MLH and/or, (2) single-locus effects of specific microsatellite loci in the Aquatic Warbler (Acrocephalus paludicola). This globally threatened passerine, a habitat specialist breeding in isolated wetlands, underwent a steep decline in population size (Briedis and Keišs 2016; Flade et al. 2018), which could have lowered its genetic diversity and increased inbreeding rates. The Aquatic Warbler is infected by blood parasites of the genera Leucocytozoon, Plasmodium, and Trypanosoma; in males, infection with trypanosomes negatively correlates with fitness-related traits (Dyrcz et al. 2005; Neto et al. 2015; Kubacka et al. 2019). These findings, converged with the previous results on haemosporidian parasites in other passerines (Merino et al. 2000; Marzal et al. 2005; Knowles et al. 2010; Martínez-de La Puente et al. 2010), indicate that blood parasitism likely affects the fitness status of the Aquatic Warbler. Therefore, this passerine comes as a good model to study HFCs related to blood parasite infection in species of conservation concern.

\section{Materials and methods}

\section{Study area and sampling}

We sampled two core breeding populations of the Aquatic Warbler in Eastern Poland, differing by size and degree of fragmentation. The Biebrza Valley population (central position: $53^{\circ} 17^{\prime} 10.6^{\prime \prime} \mathrm{N}, 22^{\circ} 33^{\prime} 41.9^{\prime \prime} \mathrm{E}$ ) is one of the largest (c. 2700 singing males), and occupies extensive and rather continuous mire habitat. The Polesie population (central position: $51^{\circ} 21^{\prime} 48.9^{\prime \prime} \mathrm{N}, 23^{\circ} 17^{\prime} 21.4^{\prime \prime} \mathrm{E}$ ), located c. $250 \mathrm{~km}$ away, holds approximately 600 singing males and breeds at several small mires scattered across a large area.

In total, we obtained blood samples from 144 Aquatic Warblers between May and August 2014 (see Online Resource 1 for a list of samples). For the purpose of this analysis, five immature individuals were excluded, as their sex was unknown and because age affects blood parasite infection (Marzal et al. 2016). Hence, the sample sizes were 50 in the Biebrza Valley (17 females, 33 males) and 89 in Polesie (18 females, 71 males). The birds were sexed by the presence of cloacal protuberance (males) or brood-patch (females) and aged by plumage (Svensson 1992). We collected the blood by puncturing the brachial vein and stored the samples in $96 \%$ ethanol until laboratory analysis.

\section{DNA extraction and microsatellite markers}

We genotyped 17 microsatellite loci (Table 1), whichdue to the project being carried out in two different laboratories-were analysed in two pools: (1) AW-02, AW-03, AW-07, AW-08, AW-10 and AW-11 (Salewski et al. 2012), and (2) AW-01, AW-04, AW-05, AW-06, AW-09 (Salewski et al. 2012), AW-12 (Salewski unpubl., used with permission; see Online Resource 2 for primer sequences), Aar3 (Hansson et al. 2000), Fhu2 (Primmer and Ellegren 1998), Pocc8 (Bensch et al. 1997), Ase19, and Ase26 (Richardson et al. 2000). In pool 1, DNA was extracted using a phenol-chloroform protocol (Sambrook and Russell 2001) and the PCR was run in $20 \mu \mathrm{l}$ volumes with $1 \times$ enhancer, $1 \times$ Taq incubation buffer without $\mathrm{MgCl}_{2}, 0.2 \mathrm{mM}$ of dNTPs, $0.5 \mu \mathrm{M}$ of each forward (5' labelled with the dyes Hex, Fam or Cy3) and reverse primer, $0.16 \mathrm{mM} \mathrm{MgCl}_{2}, 0.5$ U Taq polymerase (Merck), and 10-100 ng DNA in. The PCR program started with an initial denaturation step at $94{ }^{\circ} \mathrm{C}$ for $3 \mathrm{~min}$, followed by 30 cycles of $94{ }^{\circ} \mathrm{C}$ for $1 \mathrm{~min}$, $55^{\circ} \mathrm{C}$ for $1 \mathrm{~min}$, and $72^{\circ} \mathrm{C}$ for $1 \mathrm{~min}$, and ended with a final extension step of $72{ }^{\circ} \mathrm{C}$ for $10 \mathrm{~min}$. In pool 2, DNA was extracted using an ammonium acetate precipitation protocol based on Bruford et al. (1998) and the markers were amplified in multiplexes, using the Multiplex Manager v.1.2 (Holleley and Geerts 2009) and a multiplex PCR kit (Qiagen) 
Table 1 Microsatellite loci used to genotype Aquatic Warblers

\begin{tabular}{|c|c|c|c|c|c|c|c|}
\hline & Locus & $\begin{array}{l}\text { Proportion miss- } \\
\text { ing genotypes }\end{array}$ & $\mathrm{Na}$ & Ho & $\mathrm{He}$ & $p$ (HWE) & $\begin{array}{l}\text { Null allele } \\
\text { freq. Ooster- } \\
\text { hout }\end{array}$ \\
\hline \multirow[t]{17}{*}{ Biebrza } & AW-01 & 0.000 & 1 & 0.000 & 0.000 & n.a & 0.000 \\
\hline & AW-02 & 0.000 & 14 & 0.800 & 0.843 & 0.008 & 0.025 \\
\hline & AW-03 & 0.000 & 6 & 0.260 & 0.254 & 0.998 & -0.002 \\
\hline & AW-04 & 0.020 & 2 & 0.571 & 0.465 & 0.108 & -0.125 \\
\hline & AW- 05 & 0.040 & 2 & 0.021 & 0.021 & 0.942 & -0.011 \\
\hline & AW- 06 & 0.020 & 5 & 0.878 & 0.579 & $0.001 *$ & -0.517 \\
\hline & AW-07 & 0.000 & 2 & 0.440 & 0.471 & 0.640 & 0.033 \\
\hline & AW-08 & 0.000 & 6 & 0.560 & 0.618 & 0.952 & 0.054 \\
\hline & AW-09 & 0.060 & 2 & 0.021 & 0.021 & 0.941 & -0.011 \\
\hline & AW-10 & 0.020 & 7 & 0.306 & 0.544 & $0.000^{*}$ & $0.199 a$ \\
\hline & AW-11 & 0.000 & 5 & 0.360 & 0.621 & $0.000^{*}$ & $0.198^{\mathrm{a}}$ \\
\hline & AW-12 & 0.000 & 1 & 0.000 & 0.000 & n.a & 0.000 \\
\hline & Fhu2 & 0.020 & 13 & 0.857 & 0.881 & 0.264 & 0.015 \\
\hline & Pocc8 & 0.120 & 9 & 0.659 & 0.722 & 0.342 & 0.034 \\
\hline & Ase19 & 0.020 & 3 & 0.510 & 0.488 & $0.000^{*}$ & -0.037 \\
\hline & Ase26 & 0.060 & 14 & 0.511 & 0.793 & $0.000^{*}$ & $0.168^{\mathrm{a}}$ \\
\hline & Aar3 & 0.280 & 16 & 0.583 & 0.884 & $0.000^{*}$ & $0.169^{\mathrm{a}}$ \\
\hline \multirow[t]{17}{*}{ Polesie } & AW-01 & 0.011 & 2 & 0.011 & 0.011 & 0.957 & -0.006 \\
\hline & AW-02 & 0.045 & 17 & 0.929 & 0.862 & 0.766 & -0.042 \\
\hline & AW-03 & 0.000 & 5 & 0.292 & 0.276 & 0.013 & -0.015 \\
\hline & AW-04 & 0.034 & 3 & 0.477 & 0.464 & 0.977 & -0.013 \\
\hline & AW-05 & 0.090 & 2 & 0.012 & 0.012 & 0.955 & -0.006 \\
\hline & AW-06 & 0.000 & 5 & 0.775 & 0.553 & $0.000^{*}$ & -0.322 \\
\hline & AW-07 & 0.000 & 4 & 0.461 & 0.497 & 0.918 & 0.035 \\
\hline & AW-08 & 0.000 & 6 & 0.753 & 0.716 & 0.223 & -0.031 \\
\hline & AW-09 & 0.022 & 2 & 0.069 & 0.067 & 0.739 & -0.035 \\
\hline & AW-10 & 0.000 & 8 & 0.449 & 0.692 & $0.000^{*}$ & $0.171^{\mathrm{a}}$ \\
\hline & AW-11 & 0.022 & 4 & 0.391 & 0.635 & $0.000^{*}$ & $0.186^{\mathrm{a}}$ \\
\hline & AW-12 & 0.034 & 2 & 0.093 & 0.089 & 0.651 & -0.048 \\
\hline & Fhu2 & 0.067 & 15 & 0.904 & 0.873 & 0.927 & -0.018 \\
\hline & Pocc8 & 0.090 & 11 & 0.704 & 0.788 & $0.002^{*}$ & 0.055 \\
\hline & Ase19 & 0.090 & 7 & 0.457 & 0.478 & 0.975 & 0.028 \\
\hline & Ase26 & 0.034 & 14 & 0.628 & 0.739 & $0.000^{*}$ & $0.074^{\mathrm{a}}$ \\
\hline & Aar3 & 0.326 & 17 & 0.633 & 0.896 & $0.000^{*}$ & $0.146^{\mathrm{a}}$ \\
\hline
\end{tabular}

All calculations are population-wise. Loci AW-01, AW-10, AW-11, AW-12, Ase26, and Aar3 were excluded from the analysis

$\mathrm{Na}$ number of alleles, $\mathrm{Ho}$ observed, $\mathrm{He}$ expected heterozygosity, $\mathrm{p}(H W E) \mathrm{p}$ value of the Hardy-Weinberg test

*Significant after sequential Bonferroni correction

${ }^{\text {a }}$ Presence of null alleles according to Microchecker in $20 \mu$ volumes, with $1 \times$ Qiagen Multiplex PCR Master Mix, $0.2 \mu \mathrm{M}$ of each forward (5' labelled with Hex, Fam or Cy3) and reverse primer, $1 \times \mathrm{Q}$-Solution and 10-100 ng DNA, completed with RNase-free $\mathrm{H}_{2} \mathrm{O}$. The PCR products were sized with an ABI 3130 Avant sequencer (pool 1) and an ABI 3730xl DNA Analyzer (pool 2). Electropherograms were scored by one person (JK) using the Peakscanner software v. 1.0 (Applied Biosystems).
Both extraction methods that we applied produce yields of comparable DNA quality and quantity (Sameer et al. 2009; Mirmomeni et al. 2011). The pattern of null alleles in our sample (see Table 1) was similar to the one found in a sample collected from Aquatic Warblers in the Biebrza Valley and Polesie in another project and typed at the same microsatellite loci but with a different PCR protocol (Kubacka unpubl.). Thus, we had confidence that employing 
two different PCR protocols for our samples was unlikely to create a bias in null allele pattern and hence allele frequencies.

We used Genealex 6.5 (Peakall and Smouse 2006, 2012) to check the markers for deviation from the Hardy-Weinberg rule and the Genepop web interface (Raymond et al. 1995; Rousset 2008) to test for linkage disequilibrium, applying the sequential Bonferroni correction to the obtained $p$ values. We assessed null allele frequency using the Microchecker and the Oosterhout estimator, which is well suited for nonequilibrium populations (Van Oosterhout et al. 2006).

\section{Heterozygosity and identity disequilibrium}

As a heterozygosity metric, we used the internal relatedness (IR). IR is a measure of parental relatedness that weighs heterozygosity by allele frequency. It is calculated with the formula:

$\frac{2 H-\sum f i}{2 N-\sum f i}$

where $H$ is the number of homozygous loci in an individual, $N$ is the total number of loci, and $f_{i}$ is the frequency of the $i$ th allele in the genotype. IR assumes values between - 1 (all heterozygous) and 1 (all homozygous). Negative IR values indicate more outbred and positive IR values suggest more inbred individuals within the studied sample (Amos et al. 2001). In the case of a species with fragmented population and low expected genetic diversity due to a steep recent decline, IR appears to be superior to homozygosity by loci (HL), which is better suited for open populations with relatively high immigration rates and heterozygosity (Aparicio et al. 2006). IR is a measure of heterozygosity that yields the strongest HFCs and is highly correlated with other measures, such as heterozygosity, standardized heterozygosity, and homozygosity by loci (Chapman et al. 2009; Forstmeier et al. 2012).

To test whether the marker loci showed ID, we tested for a heterozygosity-heterozygosity correlation (HHC) (Balloux et al. 2004). The set of marker loci was randomly divided in half to see whether the heterozygosity of the first group is correlated with that of the second group across individuals. This procedure was repeated 1000 times and the mean correlation coefficient was calculated with its confidence interval. If it is significantly greater than zero, a genome-wide effect is inferred that is likely due to inbreeding. In addition, we computed the $g_{2}$ statistic, which is an indicator of variance of inbreeding in the population. $g_{2}$ quantifies the covariance of heterozygosity at the studied loci standardized by their average heterozygosity (David et al. 2007).

We calculated IR, HHC, and $g_{2}$ in the R environment (v. 3.5.1; R Core Team 2018). IR and HHC were quantified using the package Rhh (v. 1.0.2; Alho et al. 2010) and the $g_{2}$ statistic was calculated with the package inbreedR (v. 0.3.2; Stoffel et al. 2016), running 1000 permutations.

\section{Identification and diversity of blood parasites}

The blood samples were molecularly screened for the presence of blood parasites in a different project (Kubacka et al. 2019). In brief, the DNA samples extracted following the phenol-chloroform protocol were used to PCR-amplify a $478 \mathrm{bp}$ fragment of the mitochondrial cyt b gene to detect Leucocytozoon, Haemoproteus, and Plasmodium (Hellgren et al. 2004), and a $326 \mathrm{bp}$ fragment of the small subunit ribosomal RNA (SSU rRNA) gene to identify Trypanosoma (Sehgal et al. 2001). PCR products of positive samples were purified and sequenced. The obtained sequences were aligned to sequences available in the MalAvi database (Bensch et al. 2009) for Leucocytozoon, Haemoproteus, and Plasmodium, and in GenBank for Trypanosoma (BLASTN, best hit match) (Kubacka et al. 2019).

\section{Statistical analysis}

We performed the analysis in the R environment (v. 3.5.1; $\mathrm{R}$ Core Team 2018). We used the Akaike information criterion corrected for small-sample size (AICc) and the informationtheoretic approach for inference (Burnham and Anderson 2002). In this approach, in contrast with the null hypothesis testing, the researcher creates an a priori set of biologically plausible candidate models, which are given relative AICc ranks corresponding to how well they explain the data. The best-ranking model (or a subset of best models) is then selected, with models within 2 AICc units relative to the top model (which has the lowest AICc) considered to be highly supported (Burnham and Anderson 2004). Each model is given a quantitative measure of relative support, by computing model likelihood (the relative likelihood of the model in the candidate set, given the data), the Akaike weight ( $\omega \mathrm{AICc}$; the probability of the model for a given set of candidate models), and the evidence ratio (the ratio of the model's probability to the probability of the top model).

We ran two separate analyses, in both of which we used generalized linear models with binomial error structure and logit link, fitted using the 'glm' function from the stats package. First, we assessed the general heterozygosity effects on infection probability. We constructed three sets of candidate models, with the infection status by blood parasites pooled (candidate set 1), Plasmodium (candidate set 2), and Trypanosoma (candidate set 3 ) as a binary response variable, respectively. Because infection by Leucocytozoon was detected only in one individual (Kubacka et al. 2019), this genus was included in the pooled parasites models, but we did not run a separate analysis for 
it. In each of the candidate sets, the global (full) model included IR, as well as region (Biebrza or Polesie), sex (male or female) and all the two-way interactions. This allowed us to control for factors that affect infection rates and/or HFCs, such as population structure, sex, or habitat (Reid et al. 2007; Brekke et al. 2010; Szulkin et al. 2010; Sehgal 2015; Arct et al. 2017; Kubacka et al. 2019). Each candidate set contained a null model, which assumed that infection probability was constant in all individuals. By choosing this all-subset approach, we were also able to quantify the importance of IR in explaining infection, relative to sex and population. The importance of a variable is calculated by summing the Akaike weights across all the models in the set that contain this variable (Burnham and Anderson 2002). Second, to test for single-locus effects, we again constructed three sets of candidate models, with the response variables as above and the explanatory variables being the heterozygosities of the microsatellite loci, coded as 0 (homozygous) or 1 (heterozygous). Since six loci were discarded from the analyses of single-locus effects (see "Results"), there were 11 locus models. Each of the three candidate sets also included a model assuming that infection probability varied only with IR and a null model, yielding a total of 13 models in each candidate set. This enabled us to see whether any single locus explained the given infection status better than did other loci or IR, and better than the null model. Missing values (see Table 1) for a given locus were replaced by its mean heterozygosity (Szulkin et al. 2010). To ensure that missing values did not bias the results, we re-ran all the models taking standardized heterozygosity (SH) instead of IR. SH is best applied to a data set in which not all individuals are genotyped at all the loci. It is calculated by standardizing individual heterozygosity at the genotyped loci by their mean heterozygosity, thus making heterozygosity independent of the loci that are genotyped (Coltman et al. 1999).

In both analyses, the sum contrasts were used, IR was centred, and estimates were model-averaged across the 95\% confidence set of the best models (i.e., a set including the top models the cumulative $\omega$ AICc of which equals or just exceeds 0.95) to account for model selection uncertainty (Burnham and Anderson 2002). We applied the package AICcmodavg (v. 2.2-2) for model selection (Mazerolle 2019), the MuMIn package (v. 1.43.9) for calculation of model-averaged estimates along with their confidence intervals (Bartoń 2019), and the ResourceSelection package (v. 0.3-5) to run the Hosmer-Lemeshow goodness of fit test and assess whether the global model fitted the data (Hosmer and Lemeshow 2000; Lele et al. 2019).

\section{Results}

Four loci showed null alleles and two loci were monomorphic in the Biebrza population (Table 1), and we therefore discarded these six markers in further analyses. We did not detect LD among the markers (all sequential Bonferroni-corrected $p$ values $>>0.05$ ). IR ranged from -0.559 to 0.797 (mean $\pm \mathrm{SD}-0.034 \pm 0.211)$ and did not vary by sex $\left(F_{1,137}=1.66, p=0.200\right)$ or population $\left(F_{1,137}=0.88\right.$, $p=0.351)$. The HHC was not different from zero for the overall data set (mean $r=-0.053,95 \% \mathrm{CI}-0.138$ to 0.050 ), Biebrza (mean $r=0.067,95 \% \mathrm{CI}-0.079$ to 0.211 ), or Polesie (mean $r=-0.117,95 \% \mathrm{CI}-0.248$ to 0.015 ). Neither was $g_{2}$ different from zero, whether for all the individuals $\left(g_{2}=-0.003,95 \% \mathrm{CI}-0.019\right.$ to 0.015$)$, Biebrza $\left(g_{2}=0.015\right.$, $95 \% \mathrm{CI}-0.019$ to 0.059$)$, or Polesie $\left(g_{2}=-0.011,95 \% \mathrm{CI}\right.$ -0.026 to 0.006 ). The identified blood parasite lineages and infection prevalence were reported elsewhere (Kubacka et al. 2019). In brief, $31 \%, 12 \%$, and $<1 \%$ individuals were infected by Plasmodium, Trypanosoma, and Leucocytozoon, respectively. No Haemoproteus infections were detected.

\section{Heterozygosity and blood parasites: multi-locus effects}

Probability of infection by blood parasites pooled was best explained by the constant infection model. The IR model, which was within the $\leq 2 \Delta$ AICc subset, ranked third and had about twice lower probability relative to the null model (Table 2). The odds ratio (OR) corresponding to the modelaveraged estimate of the IR effect (Table 3) suggested that probability of infection by any blood parasite increases about twofold with one unit increase in IR (Fig. 1a). However, the confidence interval of the IR estimate spanned zero, indicating that the effect of IR is not truly different from null. The relative importance of IR, sex, and population was 0.42 , 0.46 , and 0.36 , respectively. The full model fitted the data well, as there was no significant difference between the fitted and the observed data $\left(X^{2}=3.98, d f=8, p=0.859\right)$. An analysis run on the data set excluding the individual parasitized by Leucocytozoon yielded similar results (not shown).

Infection by Plasmodium was also best explained by the constant infection model, with the IR model ranking second and having a similar probability (Table 2). The estimate of the IR effect suggested an approximately twofold increase of Plasmodium infection probability with one unit increase in IR (Fig. 1b); however, its confidence intervals also overlapped zero (Table 3 ). The relative importance of IR, sex, and population in explaining Plasmodium infection was $0.60,0.61$, and 0.40 , respectively. The global model fitted the data well $\left(X^{2}=5.97, d f=8\right.$, $p=0.651)$. 
Table 2 Model selection results for the relationship between probability of infection by blood parasites and internal relatedness (IR), sex, and the population of origin

\begin{tabular}{|c|c|c|c|c|c|c|c|}
\hline Model & $K^{\mathrm{a}}$ & $\mathrm{AICc}^{\mathrm{b}}$ & $\Delta \mathrm{AICc}^{\mathrm{c}}$ & Evidence ratio & $\omega \mathrm{AICc}^{\mathrm{d}}$ & Log-likelihood & $\begin{array}{l}\text { Cumu- } \\
\text { lative } \\
\text { AICc }\end{array}$ \\
\hline \multicolumn{8}{|l|}{ Blood parasites pooled } \\
\hline Null & 1 & 186.81 & 0.00 & 1.00 & 0.25 & -92.39 & 0.25 \\
\hline Sex & 2 & 187.97 & 1.15 & 0.56 & 0.14 & -91.94 & 0.39 \\
\hline IR & 2 & 188.14 & 1.33 & 0.51 & 0.13 & -92.03 & 0.52 \\
\hline Population & 2 & 188.76 & 1.94 & 0.38 & 0.10 & -92.33 & 0.62 \\
\hline $\mathrm{IR}+\operatorname{sex}$ & 3 & 189.12 & 2.31 & 0.32 & 0.08 & -91.47 & 0.70 \\
\hline Sex + population & 3 & 189.81 & 3.00 & 0.22 & 0.06 & -91.82 & 0.76 \\
\hline IR + population & 3 & 190.16 & 3.35 & 0.19 & 0.05 & -91.99 & 0.80 \\
\hline IR + sex + IR:sex & 4 & 190.52 & 3.71 & 0.16 & 0.04 & -91.11 & 0.84 \\
\hline Sex + population + sex:population & 4 & 190.69 & 3.87 & 0.14 & 0.04 & -91.19 & 0.88 \\
\hline $\mathrm{IR}+\mathrm{sex}+$ population & 4 & 191.05 & 4.24 & 0.12 & 0.03 & -91.38 & 0.91 \\
\hline IR + population + IR:population & 4 & 192.16 & 5.35 & 0.07 & 0.02 & -91.93 & 0.93 \\
\hline IR + sex + population + sex:population & 5 & 192.18 & 5.37 & 0.07 & 0.02 & -90.86 & 0.95 \\
\hline \multicolumn{8}{|l|}{ Plasmodium } \\
\hline Null & 1 & 173.99 & 0.00 & 1.00 & 0.15 & -85.98 & 0.15 \\
\hline IR & 2 & 174.50 & 0.51 & 0.78 & 0.12 & -85.21 & 0.27 \\
\hline IR + sex + IR:sex & 4 & 174.57 & 0.57 & 0.75 & 0.11 & -83.13 & 0.38 \\
\hline Sex & 2 & 174.57 & 0.57 & 0.75 & 0.11 & -85.24 & 0.49 \\
\hline IR $+\operatorname{sex}$ & 3 & 174.71 & 0.72 & 0.70 & 0.10 & -84.27 & 0.60 \\
\hline Population & 2 & 175.71 & 1.72 & 0.42 & 0.06 & -85.81 & 0.66 \\
\hline IR + sex + population + IR:sex & 5 & 175.90 & 1.90 & 0.39 & 0.06 & -82.72 & 0.72 \\
\hline Sex + population & 3 & 176.05 & 2.05 & 0.36 & 0.05 & -84.94 & 0.77 \\
\hline $\mathrm{IR}+\operatorname{sex}+$ population & 4 & 176.33 & 2.33 & 0.31 & 0.05 & -84.01 & 0.82 \\
\hline $\mathrm{IR}+$ population & 3 & 176.36 & 2.37 & 0.31 & 0.05 & -85.09 & 0.86 \\
\hline IR + sex + population + sex:population + IR:sex & 6 & 177.43 & 3.43 & 0.18 & 0.03 & -82.40 & 0.89 \\
\hline Sex + population + sex:population & 4 & 177.81 & 3.82 & 0.15 & 0.02 & -84.76 & 0.91 \\
\hline $\mathrm{IR}+\operatorname{sex}+$ population + IR:sex + IR:population & 6 & 177.96 & 3.96 & 0.14 & 0.02 & -82.66 & 0.93 \\
\hline $\mathrm{IR}+$ sex + population + sex:population & 5 & 178.28 & 4.29 & 0.12 & 0.02 & -83.92 & 0.95 \\
\hline \multicolumn{8}{|l|}{ Trypanosoma } \\
\hline Population & 2 & 104.25 & $\mathbf{0 . 0 0}$ & 1.00 & 0.21 & -50.08 & 0.21 \\
\hline Sex + population + sex:population & 4 & 104.90 & 0.66 & 0.72 & 0.15 & -48.30 & 0.36 \\
\hline Null & 1 & 105.30 & 1.06 & 0.59 & 0.12 & -51.64 & 0.48 \\
\hline Sex + population & 3 & 106.04 & 1.79 & 0.41 & 0.08 & -49.93 & 0.56 \\
\hline IR + population & 3 & 106.18 & 1.93 & 0.38 & 0.08 & $-\mathbf{5 0 . 0 0}$ & 0.64 \\
\hline $\mathrm{IR}+\operatorname{sex}+$ population + sex:population & 5 & 106.70 & 2.45 & 0.29 & 0.06 & -48.12 & 0.70 \\
\hline Sex & 2 & 106.74 & 2.49 & 0.29 & 0.06 & -51.32 & 0.76 \\
\hline IR & 2 & 107.10 & 2.85 & 0.24 & 0.05 & -51.51 & 0.81 \\
\hline $\mathrm{IR}+\operatorname{sex}+$ population & 4 & 108.02 & 3.77 & 0.15 & 0.03 & -49.86 & 0.84 \\
\hline IR + population + IR:population & 4 & 108.29 & 4.04 & 0.13 & 0.03 & -49.99 & 0.87 \\
\hline IR + sex + population + sex:population + IR:sex & 6 & 108.36 & 4.11 & 0.13 & 0.03 & -47.86 & 0.90 \\
\hline $\mathrm{IR}+\operatorname{sex}$ & 3 & 108.64 & 4.39 & 0.11 & 0.02 & -51.23 & 0.92 \\
\hline IR + sex + population + IR:population + sex:population & 6 & 108.84 & 4.59 & 0.10 & 0.02 & -48.10 & 0.94 \\
\hline IR + sex + population + IR:sex & 5 & 109.03 & 4.79 & 0.09 & 0.02 & -49.29 & 0.96 \\
\hline
\end{tabular}

$95 \%$ confidence candidate sets are presented. The models within $\leq 2 \Delta \mathrm{AICc}$ (i.e., highly supported) are marked in bold

${ }^{a}$ Number of estimable parameters

${ }^{\mathrm{b}}$ Akaike information criterion corrected for small-sample size

${ }^{c}$ Distance to the most parsimonious model in AICc units

${ }^{\mathrm{d}}$ Akaike weight (probability of a model) 
Table 3 Estimates and odds ratios (OR) of the predictors included in the three candidate sets used to determine the best models explaining infection of Aquatic Warblers by any of the blood parasites pooled, only Plasmodium and only Trypanosoma, respectively

\begin{tabular}{|c|c|c|}
\hline Model & Estimate (CI) & $\mathrm{OR}(\mathrm{CI})$ \\
\hline \multicolumn{3}{|c|}{ Blood parasites pooled } \\
\hline Intercept & $-0.53(-0.92,-0.13)$ & \\
\hline IR & $0.70(-1.00,2.40)$ & $2.01(0.37,11.05)$ \\
\hline $\operatorname{Sex}^{\mathrm{a}}$ & $-0.21(-0.62,0.21)$ & $0.81(0.54,1.23)$ \\
\hline Population $^{\mathrm{b}}$ & $0.09(-0.30,0.48)$ & $1.10(0.74,1.62)$ \\
\hline IR:sex & $-0.83(-2.76,1.10)$ & $0.44(0.06,3.02)$ \\
\hline IR:population & $0.29(-1.37,1.95)$ & $1.34(0.25,7.02)$ \\
\hline Sex:population & $0.23(-0.20,0.66)$ & $1.26(0.82,1.94)$ \\
\hline \multicolumn{3}{|l|}{ Plasmodium } \\
\hline Intercept & $-0.88(-1.33,-0.44)$ & \\
\hline IR & $0.79(-1.31,2.89)$ & $2.21(0.27,17.98)$ \\
\hline $\operatorname{Sex}^{\mathrm{a}}$ & $-0.28(-0.74,0.17)$ & $0.75(0.48,1.19)$ \\
\hline Population $^{\mathrm{b}}$ & $0.16(-0.26,0.57)$ & $1.17(0.77,1.77)$ \\
\hline IR:sex & $-1.69(-3.85,0.47)$ & $0.18(0.02,1.59)$ \\
\hline IR:population & $0.34(-1.53,2.21)$ & $1.40(0.22,9.14)$ \\
\hline Sex:population & $0.17(-0.31,0.65)$ & $1.19(0.73,1.92)$ \\
\hline \multicolumn{3}{|l|}{ Trypanosoma } \\
\hline Intercept & $-2.24(-3.01,-1.47)$ & \\
\hline IR & $-0.59(-3.39,2.20)$ & $0.55(0.03,9.03)$ \\
\hline $\operatorname{Sex}^{\mathrm{a}}$ & $-0.07(-0.87,0.73)$ & $0.93(0.42,2.08)$ \\
\hline Population $^{\mathrm{b}}$ & $-0.44(-1.20,0.32)$ & $0.65(0.30,1.38)$ \\
\hline IR:sex & $1.21(-2.08,4.51)$ & $3.37(0.12,91.07)$ \\
\hline IR:population & $-0.07(-3.25,3.12)$ & $0.93(0.04,22.54)$ \\
\hline Sex:population & $0.71(-0.12,1.53)$ & $2.03(0.89,4.63)$ \\
\hline
\end{tabular}

Due to model selection uncertainty, the estimates were averaged over the models in the $95 \%$ confidence candidate sets

CI 95\% confidence interval

${ }^{a}$ Males relative to females

${ }^{\mathrm{b}}$ Polesie relative to Biebrza

Infection by Trypanosoma was best explained by the population model, while the only model containing IR within $\Delta$ AICc $<2$ ranked fifth, with a model probability of 0.08 (Table 2). The estimate of the IR effect was also not truly different from one (Table 3, Fig. 1c). The relative importance of IR, sex, and population in explaining Trypanosoma infection was $0.38,0.51$, and 0.73 , respectively. The full model fitted the data well $\left(X^{2}=4.60, d f=8, p=0.799\right)$.

In all the analyses, the order and support for the models were nearly identical when they were run with standardized heterozygosity (SH) instead of IR (not shown).

\section{Heterozygosity and blood parasites: single-locus effects}

We found support that infection by blood parasites pooled was negatively affected by heterozygosity at locus AW-03.
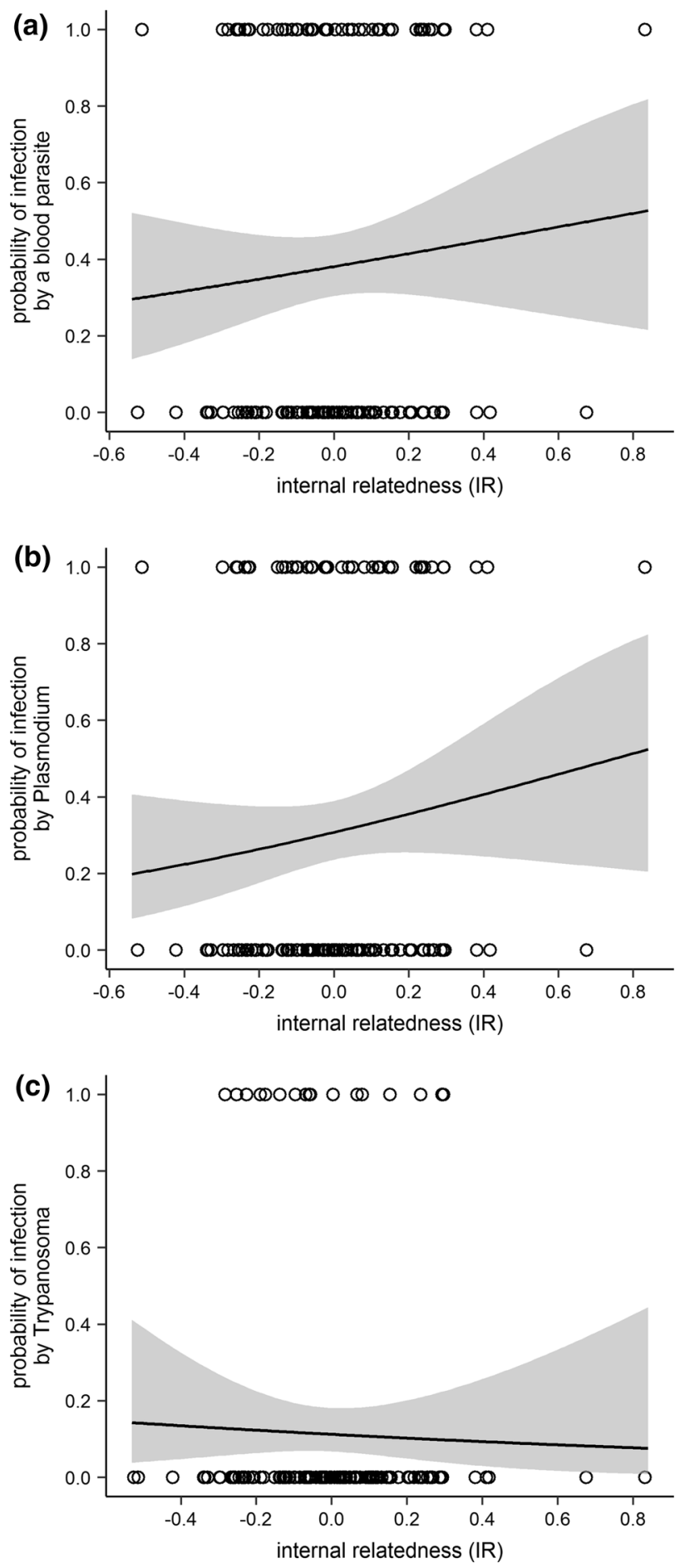

Fig. 1 Relationship between internal relatedness (IR, centred) and the probability of infection by a at least one of the blood parasites identified in the study (Plasmodium, Trypanosoma, or Leucocytozoon), b Plasmodium, and c Trypanosoma. The lines were fitted based on the estimates from the top models that included IR (Table 2). Bands show confidence intervals and the circles represent the distribution of samples ( 0 - uninfected; 1 -infected). None of the associations was clearly supported by the data (see Tables 2 and 3 ) 
The AW-03 model was the only one within $\Delta \mathrm{AICc}<2$; it was 9.8 times more probable than the IR model and 5.6 times more probable than the constant infection model (Table 4). The AW-03 estimate was -0.96 (95\% CI -1.81 to -0.12 ) and its OR was 0.38 (95\% CI 0.16-0.89), indicating that individuals heterozygous at the AW-03 locus were 0.38 times less likely to carry blood parasite infection relative to homozygous individuals.

Infection by Plasmodium was best explained by the Ase 19 and AW-03 models, which were the only ones within $\Delta$ AICc $<2$. The top model, containing the Ase19 locus, was 4.3 times more probable than the IR model and 3.3 times more probable than the null model (Table 4). The Ase19 estimate was -0.82 (95\% CI -1.6 to -0.05 ), OR 0.44 (95\% CI 0.20-0.95); the AW-03 estimate was -0.74 (95\% CI -1.61 to 0.14 ), OR 0.48 (95\% CI $0.20-1.15$ ). Therefore, in individuals heterozygous at Ase19, the probability of infection with Plasmodium was 0.44 of that of homozygous individuals, while the effect of AW-03 was weakly supported, as the CIs of its OR spanned one.

There was considerable model selection uncertainty concerning Trypanosoma infection models, with none of the loci receiving clearly better support than the other loci or IR (Table 4). No estimates of the $\Delta \mathrm{AICc}<2$ models showed an effect on infection probability, as all of their $95 \%$ CIs spanned zero (not shown). In all the three analyses, the order and support for models was also very similar when SH was used instead of IR (not shown).

\section{Discussion}

\section{Heterozygosity: genome-wide effects}

We did not find strong evidence for an association between multi-locus heterozygosity and the incidence of infection by blood parasites in the Aquatic Warbler, a rare bird species that has gone through a dramatic decline in numbers and geographical range. Therefore, in our study, the relationship between MLH and infection status in this species cannot be convincingly explained by the general effects of heterozygosity. Still, heterozygosity appears to be a relatively important predictor of Plasmodium infection incidence in the Aquatic Warbler. Our results also indicate that heterozygosity has different importance as a predictor of infection by Plasmodium and by Trypanosoma, as it poorly explained infection by the latter.

Studies on birds that related infection by blood parasites to MLH have yielded mixed results. In Blue Tits (Cyanistes caeruleus), MLH at microsatellite markers showed a negative quadratic relationship with the probability of infection by Plasmodium relictum (Ferrer et al.
2014). In the Common Buzzard (Buteo buteo), MLH was correlated with infection by Leucocytozoon buteonis through interaction with vole abundance and age of individuals (Boerner et al. 2013). In American Crows (Corvus brachyrhynchos), lower heterozygosity was associated with infection of offspring, but not adults, by Plasmodium spp. (Townsend et al. 2018a). However, other avian studies failed to find any relationship (Ortego et al. 2007; Vallender et al. 2012).

Our study was hampered by the lack of polymorphism of some of the microsatellite loci and presence of null alleles, which led to exclusion of 6 out of the 17 markers. The low final number of markers, together with their moderate polymorphism (Table 1), could explain why we did not find firm support for the effect of MLH on blood parasite infection status (Hansson and Westerberg 2002; Balloux et al. 2004; Slate et al. 2004; Ljungqvist et al. 2010; Forstmeier et al. 2012). On the other hand, it was also emphasized that finding an HFC is dependent on the variance in inbreeding rates (Hansson and Westerberg 2002; Csilléry et al. 2006; Ljungqvist et al. 2010; Taylor et al. 2010; Forstmeier et al. 2012). The isolation of breeding sites, the relatively high breeding philopatry, the skewed paternities and the recent steep decline of the Aquatic Warbler (Dyrcz et al. 2002, 2005; Briedis and Keišs 2016; Bellebaum 2018; Flade et al. 2018) indicate that in this species, increased variation in inbreeding could be expected. Nevertheless, we found a low variance in inbreeding $\left(g_{2}\right)$, which suggests low variation in relatedness in the studied areas.

It is also possible that MLH better explains quantitative infection rates, rather than infection probability, as the latter does not differentiate between acute and chronic infection. For example, in mountain White-crowned Sparrows (Zonotrichia leucophrys oriantha), the intensity of infection with hematozoan parasites was lower in more heterozygous individuals (MacDougall-Shackleton et al. 2005), and in Banded Mongooses (Mungos mungo), individuals with increased heterozygosity had lower intestinal parasite loads (Mitchell et al. 2017). Infection status might also be related to MLH only in a harsher environment (Boerner et al. 2013; Annavi et al. 2014). Finally, the genetic mechanism underlying resistance to blood parasites could be a trait determined by one or a few genes, making it less likely to observe correlation of genome-wide heterozygosity with blood parasite resistance (Szulkin et al. 2010; Bateson et al. 2016).

\section{Heterozygosity: single-locus effects}

We observed local effects of loci AW-03 and Ase19, which predicted a lower infection probability by the studied blood parasites taken together, and by Plasmodium, respectively, 
Table 4 Model selection results for the relationship between probability of infection by blood parasites and single-locus heterozygosity

\begin{tabular}{|c|c|c|c|c|c|c|c|}
\hline Model & $K^{\mathrm{a}}$ & $\mathrm{AICc}^{\mathrm{b}}$ & $\Delta \mathrm{AICc}^{\mathrm{c}}$ & Evidence ratio & $\omega \mathrm{AICc}^{\mathrm{d}}$ & Log-likelihood & $\begin{array}{l}\text { Cumula- } \\
\text { tive AICc }\end{array}$ \\
\hline \multicolumn{8}{|c|}{ Blood parasites pooled } \\
\hline AW-03 & 2 & 183.41 & 0.00 & 1.00 & 0.39 & -89.66 & 0.39 \\
\hline AW-09 & 2 & 185.79 & 2.38 & 0.30 & 0.12 & -90.85 & 0.51 \\
\hline AW-02 & 2 & 186.72 & 3.31 & 0.19 & 0.08 & -91.32 & 0.59 \\
\hline Null & 1 & 186.81 & 3.40 & 0.18 & 0.07 & -92.39 & 0.66 \\
\hline Ase19 & 2 & 186.93 & 3.52 & 0.17 & 0.07 & -91.42 & 0.73 \\
\hline AW-08 & 2 & 187.42 & 4.01 & 0.13 & 0.05 & -91.67 & 0.78 \\
\hline AW-06 & 2 & 188.06 & 4.65 & 0.10 & 0.04 & -91.99 & 0.82 \\
\hline IR & 2 & 188.14 & 4.73 & 0.09 & 0.04 & -92.03 & 0.86 \\
\hline AW-04 & 2 & 188.40 & 4.99 & 0.08 & 0.03 & -92.16 & 0.89 \\
\hline Pocc8 & 2 & 188.61 & 5.20 & 0.07 & 0.03 & -92.26 & 0.92 \\
\hline Fhu2 & 2 & 188.67 & 5.26 & 0.07 & 0.03 & -92.29 & 0.95 \\
\hline AW-07 & 2 & 188.76 & 5.35 & 0.07 & 0.03 & -92.33 & 0.97 \\
\hline AW-05 & 2 & 188.77 & 5.36 & 0.07 & 0.03 & -92.34 & 1.00 \\
\hline \multicolumn{8}{|c|}{ Plasmodium } \\
\hline Ase19 & 2 & 171.54 & 0.00 & 1.00 & 0.30 & -83.72 & 0.30 \\
\hline AW-03 & 2 & 173.16 & 1.62 & 0.44 & 0.13 & -84.53 & 0.43 \\
\hline Null & 1 & 173.99 & 2.46 & 0.29 & 0.09 & -85.98 & 0.52 \\
\hline AW-08 & 2 & 174.30 & 2.76 & 0.25 & 0.08 & -85.11 & 0.60 \\
\hline IR & 2 & 174.50 & 2.96 & 0.23 & 0.07 & -85.21 & 0.67 \\
\hline AW-06 & 2 & 174.91 & 3.37 & 0.19 & 0.06 & -85.41 & 0.72 \\
\hline AW-02 & 2 & 174.95 & 3.42 & 0.18 & 0.05 & -85.43 & 0.78 \\
\hline Pocc8 & 2 & 175.03 & 3.49 & 0.17 & 0.05 & -85.47 & 0.83 \\
\hline AW-09 & 2 & 175.67 & 4.13 & 0.13 & 0.04 & -85.79 & 0.87 \\
\hline AW-05 & 2 & 175.76 & 4.22 & 0.12 & 0.04 & -85.84 & 0.90 \\
\hline Fhu2 & 2 & 175.90 & 4.36 & 0.11 & 0.03 & -85.90 & 0.94 \\
\hline AW-07 & 2 & 176.02 & 4.48 & 0.11 & 0.03 & -85.97 & 0.97 \\
\hline AW-04 & 2 & 176.05 & 4.52 & 0.10 & 0.03 & -85.98 & 1.00 \\
\hline \multicolumn{8}{|c|}{ Trypanosoma } \\
\hline Null & 1 & 105.30 & 0.00 & 1.00 & 0.15 & -51.64 & 0.15 \\
\hline AW-09 & 2 & 106.00 & 0.70 & 0.70 & 0.11 & -50.96 & 0.26 \\
\hline AW-03 & 2 & 106.23 & 0.93 & 0.63 & 0.10 & -51.07 & 0.36 \\
\hline Fhu2 & 2 & 106.65 & 1.34 & 0.51 & 0.08 & -51.28 & 0.44 \\
\hline AW-02 & 2 & 106.78 & 1.48 & 0.48 & 0.07 & -51.35 & 0.51 \\
\hline AW-04 & 2 & 106.88 & 1.58 & 0.45 & 0.07 & -51.40 & 0.58 \\
\hline AW-05 & 2 & 106.94 & 1.63 & 0.44 & 0.07 & -51.42 & 0.65 \\
\hline IR & 2 & 107.10 & 1.80 & 0.41 & 0.06 & -51.51 & 0.71 \\
\hline Pocc8 & 2 & 107.20 & 1.89 & 0.39 & 0.06 & -51.55 & 0.77 \\
\hline AW-07 & 2 & 107.23 & 1.92 & 0.38 & 0.06 & -51.57 & 0.83 \\
\hline Ase19 & 2 & 107.25 & 1.94 & 0.38 & 0.06 & -51.58 & 0.89 \\
\hline AW-08 & 2 & 107.32 & 2.01 & 0.37 & 0.06 & -51.61 & 0.94 \\
\hline AW-06 & 2 & 107.34 & 2.04 & 0.36 & 0.06 & -51.63 & 1.00 \\
\hline
\end{tabular}

$I R$ Internal relatedness

${ }^{a}$ Number of estimable parameters

${ }^{\mathrm{b}}$ Akaike information criterion corrected for small-sample size

${ }^{c}$ Distance to the most parsimonious model in AICc units

${ }^{\mathrm{d}}$ Akaike weight (probability of a model) 
when in heterozygous state. This indicates that AW-03 and Ase19 are in linkage disequilibrium with unidentified fitness loci, which confer a heterozygote advantage in the Aquatic Warbler.

Linkage disequilibrium between selected and apparently neutral loci can arise due to selection, population sub-structuring, and genetic bottleneck. However, unless recombination is low or suppressed, LD is disrupted with time (Hartl and Clark 2007). The severe decline experienced by the Aquatic Warbler during the last $100-150$ years (Briedis and Keišs 2016; Flade et al. 2018) could have increased LD in its genome. Yet, our analyses of the same samples do not support a historical or recent genetic bottleneck in the study populations and no population sub-structuring was found between them (Kubacka unpubl.). Consequently, it is plausible that the association between heterozygosity of Ase19 and AW-03 and infection status in the Aquatic Warbler stems from their linkage with functional loci, such as those related to parasite resistance or infection clearance. Earlier research provides support for the association between Ase19 and immunity. In nestlings of the Bluethroat (Luscinia svecica), heterozygosity at this marker positively correlated with wing-web swelling following injection of phytohaemagglutinin (PHA) (Fossøy et al. 2009). In birds, response to PHA is associated with both innate and adaptive (T-cells) components of the immune system (Palacios et al. 2009; Vinkler et al. 2010; Salaberria et al. 2013). It is also positively related to the probability of recovery from infection with Haemoproteus sp. (Gonzalez et al. 1999).

In general, our results add to the increasing evidence that single-locus effects could underlie HFCs more than it was acknowledged earlier. Single-locus effects have been reported in previous HFC studies on wild-ranging animals (Hansson et al. 2004; Lieutenant-Gosselin and Bernatchez 2006; Ortego et al. 2007; Kaeuffer et al. 2008; Fossøy et al. 2009; Vangestel et al. 2011; García-Navas et al. 2014; Minias et al. 2015; Judson et al. 2018). However, only a few HFC studies related to disease documented local effects (Acevedo-Whitehouse et al. 2006, 2009; Amos and Acevedo-Whitehouse 2009) and, to our knowledge, our study is the first to show them in a diseaserelated study on a bird.

The local effects of Ase19 and AW-03 could help indicate genomic regions that are under parasite-mediated selection, as pointed out by Acevedo-Whitehouse et al. (2009). In addition, as they suggest a heterozygote advantage at functional genes, they also imply that factors affecting genetic diversity in the Aquatic Warbler, such as the constant loss of habitats and the resulting genetic drift, could impact blood parasite resistance in this species. Finally, these local effects can be applied in conservation management of the species to identify individuals or populations resistant to blood parasites, for instance in translocation projects (Grueber et al. 2008).

\section{Conclusion}

While we found that internal relatedness at microsatellite loci appears to be an informative predictor of Plasmodium infection in the Aquatic Warbler, our results do not provide a solid support for a negative inbreeding effect on blood parasitism in this species. However, they demonstrate a case for single-locus effects on disease probability in birds, which, to our knowledge, has not been reported before. For the Aquatic Warbler, the observed local effects could have meaningful conservation implications. In general, they add to the accumulating evidence that local effects could underpin apparent genome-wide HFCs.

Acknowledgements This work was funded by British Ornithologists' Union Career Development Bursary to Justyna Kubacka, Evolutionary Biology and Ecology lab at the University of Freiburg, Museum and Institute of Zoology of the Polish Academy of Sciences, and grants by National Science Centre, Poland: 2011/03/N/NZ8/02106 to Edyta Podmokła and 2016/20/S/NZ8/00434 to Justyna Kubacka. We greatly thank J. Foucher and several volunteers for extensive help with data collection in the field. A. Sztencel-Jabłonka and H. PanagiotopoulouStawnicka provided advice with microsatellite analysis. V. Salewski kindly provided the primer sequences of the AW-12 locus. We are grateful to anonymous reviewers for their comments on previous drafts of the manuscript.

Author contributions JKu formulated questions, obtained BOU funding, collected samples, conducted lab work, analyzed the data, and drafted the paper. EP contributed funding, conducted lab work, and contributed to writing. JKo supported the BOU grant proposal, contributed resources, and supervised lab work. AD contributed funding and supervised lab work. All the authors revised drafts.

Data availability The full data set generated during this study is available from the corresponding author on reasonable request. The input files and the $\mathrm{R}$ code used in the analysis have been published in the Mendley Data repository (https://doi.org/10.17632/rcb8czrpfj.1).

\section{Compliance with ethical standards}

Conflict of interest The authors declare that they have no conflict of interest.

Ethical approval All applicable international, national, and institutional guidelines for the care and use of animals were followed. All procedures performed involving animals were in accordance with the ethical standards of the institution at which the studies were conducted. The protocol and procedure of blood-sampling were ethically reviewed and approved of by the 1st Ethical Committee in Lublin, Poland (decision no. 17/2014 of 25 April 2014). The birds were caught and ringed under permissions from the Polish Ministry of the Environment (decision no. DLP-III-4102343125042/14/md and ringing permit no. 144/2014), the Biebrza National Park, the Poleski National Park, and the Regional Directorate for Environmental Protection in Lublin (permits no. WPN.6401.104.2014.MPR and WPN.6205.1.23.2014.MO), as required by the Polish Nature Protection Act. 
Open Access This article is licensed under a Creative Commons Attribution 4.0 International License, which permits use, sharing, adaptation, distribution and reproduction in any medium or format, as long as you give appropriate credit to the original author(s) and the source, provide a link to the Creative Commons licence, and indicate if changes were made. The images or other third party material in this article are included in the article's Creative Commons licence, unless indicated otherwise in a credit line to the material. If material is not included in the article's Creative Commons licence and your intended use is not permitted by statutory regulation or exceeds the permitted use, you will need to obtain permission directly from the copyright holder. To view a copy of this licence, visit http://creativecommons.org/licenses/by/4.0/.

\section{References}

Acevedo-Whitehouse K, Spraker TR, Lyons E et al (2006) Contrasting effects of heterozygosity on survival and hookworm resistance in California sea lion pups. Mol Ecol 15:1973-1982. https ://doi.org/10.1111/j.1365-294X.2006.02903.x

Acevedo-Whitehouse K, Petetti L, Duignan P, Castinel A (2009) Hookworm infection, anaemia and genetic variability of the New Zealand sea lion. Proc R Soc B Biol Sci 276:3523-3529. https://doi.org/10.1098/rspb.2009.1001

Alho JS, Välimäki K, Merilä J (2010) Rhh: an R extension for estimating multilocus heterozygosity and heterozygosity-heterozygosity correlation. Mol Ecol Resour 10:720-722. https ://doi.org/10.1111/j.1755-0998.2010.02830.x

Amos W, Acevedo-Whitehouse K (2009) A new test for genotypefitness associations reveals a single microsatellite allele that strongly predicts the nature of tuberculosis infections in wild boar. Mol Ecol Resour 9:1102-1111. https://doi.org/10.111 1/j.1755-0998.2009.02560.x

Amos W, Balmford A (2001) When does conservation genetics matter? Heredity (Edinb) 87:257-265. https://doi.org/10.104 6/j.1365-2540.2001.00940.x

Amos W, Worthington Wilmer J, Fullard K et al (2001) The influence of parental relatedness on reproductive success. Proc R Soc London B Biol Sci 268:2021-2027. https://doi.org/10.1098/ rspb.2001.1751

Annavi G, Newman C, Buesching CD et al (2014) Heterozygosityfitness correlations in a wild mammal population: Accounting for parental and environmental effects. Ecol Evol 4:2594-2609. https://doi.org/10.1002/ece3.1112

Aparicio JM, Ortego J, Cordero PJ (2006) What should we weigh to estimate heterozygosity, alleles or loci? Mol Ecol 15:46594665. https://doi.org/10.1111/j.1365-294X.2006.03111.x

Arct A, Sudyka J, Podmokła E et al (2017) Heterozygosity-fitness correlations in blue tit nestlings (Cyanistes caeruleus) under contrasting rearing conditions. Evol Ecol 31:803-814. https:// doi.org/10.1007/s10682-017-9911-6

Atkinson CT, Van Riper III C (1991) Pathogenicity and epozootiology of avian hematozoa: Plasmodium, Leucocytozoon and Haemoproteus. In: Loye JE, Zuk M (eds) Bird-parasite interactions. Ecology, evolution and behaviour. Oxford University Press, Oxford, pp 19-48

Balloux F, Amos W, Coulson T (2004) Does heterozygosity estimate inbreeding in real populations? Mol Ecol 13:3021-3031. https ://doi.org/10.1111/j.1365-294X.2004.02318.x

Bartoń K (2019) MuMIn: multi-model inference. R package version 1.43 .6

Bateson ZW, Hammerly SC, Johnson JA et al (2016) Specific alleles at immune genes, rather than genome-wide heterozygosity, are related to immunity and survival in the critically endangered
Attwater's prairie-chicken. Mol Ecol 25:4730-4744. https:// doi.org/10.1111/mec.13793

Beier JC, Strandberg J, Stoskopf MK, Craft C (1981) Mortality in robins (Turdus migratorius) due to avian malaria. J Wildl Dis 17:247-250. https://doi.org/10.7589/0090-3558-17.2.247

Bellebaum J (2018) Population dynamics. In: Tanneberger F, Kubacka $\mathrm{J}$ (eds) The aquatic warbler conservation handbook. Brandenburg State Office for Environment (LfU), Potsdam, pp 68-71

Bensch S, Price T, Kohn J (1997) Isolation and characterization of microsatellite loci in a Phylloscopus warbler. Mol Ecol 6:91-92. https://doi.org/10.1046/j.1365-294X.1997.00150.x

Bensch S, Hellgren O, Pérez-TRIS J (2009) MalAvi: a public database of malaria parasites and related haemosporidians in avian hosts based on mitochondrial cytochrome b lineages. Mol Ecol Resour 9:1353-1358. https://doi.org/10.1111/j.1755-0998.2009.02692.x

Boerner M, Hoffman JI, Amos W et al (2013) No correlation between multi-locus heterozygosity and fitness in the common buzzard despite heterozygote advantage for plumage colour. J Evol Biol 26:2233-2243. https://doi.org/10.1111/jeb.12221

Brekke P, Bennett PM, Wang J et al (2010) Sensitive males: inbreeding depression in an endangered bird. Proc R Soc Lond B Biol Sci 277:3677-3684. https://doi.org/10.1098/rspb.2010.1144

Briedis M, Keišs O (2016) Extracting historical population trends using archival ringing data-an example: the globally threatened Aquatic Warbler. J Ornithol 157:419-425. https://doi. org/10.1007/s10336-015-1306-2

Bruford MW, Hanotte O, Brookfield JFY, Burke T (1998) Multilocus and single-locus DNA fingerprinting. In: Hoelzel AR (ed) Molecular genetic analysis of populations: a practical approach, 2nd edn. IRL Press, Oxford, pp 287-336

Burnham KP, Anderson DR (2002) Model selection and multimodel inference: a practical information-theoretic approach, 2nd edn. Springer-Verlag, New York

Burnham KP, Anderson DR (2004) Multimodel inference: understanding AIC and BIC in model selection. Soc Methods Res 33:261304. https://doi.org/10.1177/0049124104268644

Cézilly F, Quinard A, Motreuil S, Pradel R (2016) Adult survival selection in relation to multilocus heterozygosity and body size in a tropical bird species, the Zenaida dove, Zenaida aurita. Oecologia 180:127-136. https://doi.org/10.1007/s00442-015-3466-4

Chapman JR, Nakagawa S, Coltman DW et al (2009) A quantitative review of heterozygosity-fitness correlations in animal populations. Mol Ecol 18:2746-2765. https://doi.org/10.1111/j.1365294X.2009.04247.x

Coltman DW, Pilkington JG, Smith JA, Pemberton JM (1999) Parasitemediated selection against Inbred Soay Sheep in a free-living, Island population. Evolution (N Y) 53:1259-1267

Csilléry K, Johnson T, Beraldi D et al (2006) Performance of markerbased relatedness estimators in natural populations of outbred vertebrates. Genetics 173:2091-2101

David P, Pujol B, Viard F et al (2007) Reliable selfing rate estimates from imperfect population genetic data. Mol Ecol 16:2474-2487. https://doi.org/10.1111/j.1365-294X.2007.03330.x

Dyrcz A, Wink M, Backhaus A et al (2002) Correlates of multiple paternity in the Aquatic Warbler (Acrocephalus paludicola). J für Ornithol 143:430-439. https://doi.org/10.104 6/j.1439-0361.2002.02013.x

Dyrcz A, Wink M, Kruszewicz A, Leisler B (2005) Male reproductive success Is correlated with blood parasite levels and body condition in the promiscuous Aquatic Warbler (Acrocephalus paludicola). Auk 122:558-565. https://doi.org/10.1642/0004-8038

Ferrer ES, García-Navas V, Sanz JJ, Ortego J (2014) Individual genetic diversity and probability of infection by avian malaria parasites in blue tits (Cyanistes caeruleus). J Evol Biol 27:2468-2482. https://doi.org/10.1111/jeb.12489 
Flade M, Malashevich U, Krogulec J et al (2018) World distribution, population, and trends. In: Tanneberger F, Kubacka J (eds) The Aquatic Warbler conservation handbook. Brandenburg State Office for Environment (LfU), Potsdam, pp 22-35

Forstmeier W, Schielzeth H, Mueller JC et al (2012) Heterozygosityfitness correlations in zebra finches: Microsatellite markers can be better than their reputation. Mol Ecol 21:3237-3249. https:// doi.org/10.1111/j.1365-294X.2012.05593.X

Fossøy F, Johnsen A, Lifjeld JT (2009) Cell-mediated immunity and multi-locus heterozygosity in bluethroat nestlings. J Evol Biol 22:1954-1960. https://doi.org/10.1111/j.1420-9101.2009.01790 . $\mathrm{x}$

Frankham R (2005) Genetics and extinction. Biol Conserv 126:131140. https://doi.org/10.1016/j.biocon.2005.05.002

García-Navas V, Cáliz-Campal C, Ferrer ES et al (2014) Heterozygosity at a single locus explains a large proportion of variation in two fitness-related traits in great tits: a general or a local effect? J Evol Biol 27:2807-2819. https://doi.org/10.1111/jeb.12539

Gilman S, Blumstein DT, Foufopoulos J (2007) The effect of hemosporidian infections on white-crowned sparrow singing behavior. Ethology 113:437-445. https://doi.org/10.111 1/j.1439-0310.2006.01341.x

Gonzalez G, Sorci G, Møller AP et al (1999) Immunocompetence and condition-dependent sexual advertisement in male house sparrows (Passer domesticus). J Anim Ecol 68:1225-1234. https:// doi.org/10.1046/j.1365-2656.1999.00364.x

Grueber CE, Wallis GP, Jamieson IANG (2008) Heterozygosity-fitness correlations and their relevance to studies on inbreeding depression in threatened species. Mol Ecol 17:3978-3984. https://doi. org/10.1111/j.1365-294X.2008.03910.x

Hakkarainen H, Ilmonen P, Koivunen V, Korpimäki E (1998) Blood parasites and nest defense behaviour of Tengmalm's Owls. Oecologia 114:574-577. https://doi.org/10.1007/s004420050482

Hamilton WD, Zuk M (1982) Heritable true fitness and bright birds: a role for parasites? Science (80-) 218:384-387

Hansson B, Westerberg L (2002) On the correlation between heterozygosity and fitness in natural populations. Mol Ecol 11:24672474. https://doi.org/10.1046/j.1365-294X.2002.01644.x

Hansson B, Bensch S, Hasselquist D et al (2000) Increase of genetic variation over time in a recently founded population of great reed warblers (Acrocephalus arundinaceus) revealed by microsatellites and DNA fingerprinting. Mol Ecol 9:1529-1538. https://doi. org/10.1046/j.1365-294x.2000.01028.x

Hansson B, Westerdahl H, Hasselquist D et al (2004) Does linkage disequilibrium generate heterozygosity-fitness correlations in great reed warblers? Evolution (N Y) 58:870-879. https://doi. org/10.1111/j.0014-3820.2004.tb00418.x

Hartl DL, Clark AG (2007) Principles of population genetics, 4th edn. Sinauer Associates, Inc. Publishers, Sunderland

Hellgren O, Waldenström J, Bensch S (2004) A new PCR assay for simultaneous studies of Leucocytozoon, Plasmodium, and Haemoproteus from avian blood. J Parasitol 90:797-802. https ://doi.org/10.1645/GE-184R1

Holleley CE, Geerts PG (2009) Multiplex Manager 1.0: a cross-platform computer program that plans and optimizes multiplex PCR. Biotechniques 46:511-517. https://doi.org/10.2144/000113156

Hosmer DW, Lemeshow S (2000) Applied logistic regression. Wiley, New York

Ilgūnas M, Bukauskaitė D, Palinauskas V et al (2016) Mortality and pathology in birds due to Plasmodium (Giovannolaia) homocircumflexum infection, with emphasis on the exoerythrocytic development of avian malaria parasites. Malar J 15:256. https://doi. org/10.1186/s12936-016-1310-x

Judson JLM, Knapp CR, Welch ME (2018) Age-dependent, negative heterozygosity-fitness correlations and local effects in an endangered Caribbean reptile, Iguana delicatissima. Ecol Evol 8:2088-2096. https://doi.org/10.1002/ece3.3826

Kaeuffer R, Réale D, Pontier D et al (2008) Local effects of inbreeding on embryo number and consequences for genetic diversity in Kerguelen mouflon. Biol Lett 4:504-507. https://doi. org/10.1098/rsbl.2008.0222

Knowles SCL, Palinauskas V, Sheldon BC (2010) Chronic malaria infections increase family inequalities and reduce parental fitness: experimental evidence from a wild bird population. J Evol Biol 23:557-569. https://doi.org/10.1111/j.1420-9101.2009.01920.x

Krama T, Krams R, Cīrule D et al (2015) Intensity of haemosporidian infection of parids positively correlates with proximity to water bodies, but negatively with host survival. J Ornithol 156:10751084. https://doi.org/10.1007/s10336-015-1206-5

Kubacka J, Gerlée A, Foucher J et al (2019) Correlates of blood parasitism in a threatened marshland passerine: infection by kinetoplastids of the genus Trypanosoma is related to landscape metrics of habitat edge. Parasitology 146:1036-1046. https://doi. org/10.1017/S0031182019000350

Lele SR, Keim JL, Solymos P (2019) ResourceSelection: resource selection (Probability) functions for use-availability data. R package version $0.3-5$

Lieutenant-Gosselin M, Bernatchez L (2006) Local heterozygosityfitness correlations with global positive effects on fitness in threespine stickleback. Evolution (N Y) 60:1658-1668. https://doi. org/10.1554/05-459.1

Ljungqvist M, Akesson M, Hansson B (2010) Do microsatellites reflect genome-wide genetic diversity in natural populations? A comment on Vali et al. (2008). Mol Ecol 19:851-855. https://doi. org/10.1111/j.1365-294X.2010.04522.x

MacDougall-Shackleton EA, Derryberry EP, Foufopoulos J et al (2005) Parasite-mediated heterozygote advantage in an outbred songbird population. Biol Lett 1:105-107. https://doi.org/10.1098/ rsbl.2004.0264

Martínez-de La Puente J, Merino S, Tomás G et al (2010) The blood parasite Haemoproteus reduces survival in a wild bird: a medication experiment. Biol Lett 6:663-665. https://doi.org/10.1098/ rsbl.2010.0046

Marzal A (2012) Recent advances in studies on avian malaria parasites. In: Okwa DO (ed) Malaria parasites. InTech, Rijeka, pp 135-159

Marzal A, de Lope F, Navarro C, Møller AP (2005) Malarial parasites decrease reproductive success: an experimental study in a passerine bird. Oecologia 142:541-545. https://doi.org/10.1007/ s00442-004-1757-2

Marzal A, Balbontín J, Reviriego M et al (2016) A longitudinal study of age-related changes in Haemoproteus infection in a passerine bird. Oikos 125:1092-1099. https://doi.org/10.1111/ oik.02778

Mazerolle MJ (2019) AICcmodavg: model selection and multimodel inference based on (Q)AIC(c). R package version 2.2-2

Merino S, Moreno J, Sanz JJ, Arriero E (2000) Are avian blood parasites pathogenic in the wild? A medication experiment in Blue Tits (Parus caeruleus). Proc R Soc Lond Ser B Biol Sci 267:2507-2510. https://doi.org/10.1098/rspb.2000.1312

Minias P, Wojczulanis-Jakubas K, Rutkowski R, Kaczmarek K (2015) Local heterozygosity effects on nestling growth and condition in the great cormorant. Evol Biol 42:452-460. https://doi. org/10.1007/s11692-015-9339-2

Mirmomeni MH, Sajjadi Ma S, Sisakhtnez S, Doranegard F (2011) Comparison of the three methods for DNA extraction from paraffin-embedded tissues. J Biol Sci 10:261-266. https://doi. org/10.3923/jbs.2010.261.266

Mitchell J, Vitikainen EIK, Wells DA et al (2017) Heterozygosity but not inbreeding coefficient predicts parasite burdens in the banded mongoose. J Zool 302:32-39. https://doi.org/10.1111/jzo.12424 
Møller AP, Nielsen JT (2007) Malaria and risk of predation: a comparative study of birds. Ecology 88:871-881. https://doi. org/10.1890/06-0747

Molyneux DH, Cooper JE, Smith WJ (1983) Studies on the pathology of an avian trypanosome (T. bouffardi) infection in experimentally infected canaries. Parasitology 87:49-54. https://doi. org/10.1017/S0031182000052409

Morand S, Poulin R (2000) Nematode parasite species richness and the evolution of spleen size in birds. Can J Zool 78:1356-1360. https://doi.org/10.1139/z00-076

Neto JM, Pérez-Rodríguez A, Haase M et al (2015) Prevalence and diversity of Plasmodium and Haemoproteus parasites in the globally-threatened Aquatic Warbler Acrocephalus paludicola. Parasitology 142:1183-1189. https://doi.org/10.1017/S0031 182015000414

Ortego J, Cordero PJ, Aparicio JM, Calabuig G (2007) No relationship between individual genetic diversity and prevalence of avian malaria in a migratory kestrel. Mol Ecol 16:4858-4866. https://doi.org/10.1111/j.1365-294X.2007.03554.X

Palacios MG, Cunnick JE, Vleck D, Vleck CM (2009) Ontogeny of innate and adaptive immune defense components in freeliving tree swallows, Tachycineta bicolor. Dev Comp Immunol 33:456-463. https://doi.org/10.1016/j.dci.2008.09.006

Peakall R, Smouse PE (2006) GENALEX 6: genetic analysis in excel. Population genetic software for teaching and research. Mol Ecol Notes 6:288-295. https://doi.org/10.111 1/j.1471-8286.2005.01155.x

Peakall R, Smouse PE (2012) GenALEx 6.5: genetic analysis in excel. Population genetic software for teaching and research-an update. Bioinformatics 28:2537-2539. https://doi.org/10.1093/ bioinformatics/bts 460

Pemberton J (2004) Measuring inbreeding depression in the wild: the old ways are the best. Trends Ecol Evol 19:613-615. https ://doi.org/10.1016/j.tree.2004.09.010

Primmer CR, Ellegren H (1998) Patterns of molecular evolution in avian microsatellites. Mol Biol Evol 15:997-1008

R Core Team (2018) R: a language and environment for statistical computing. Vienna, Austria. https://www.R-project.org/

Rätti O, Dufva R, Alatalo RV (1993) Blood parasites and male fitness in the pied flycatcher. Oecologia 96:410-414. https://doi. org/10.1007/BF00317512

Raymond M, Rousset F (1995) GENEPOP (Version 1.2): population genetics software for exact tests and ecumenicism. J Hered 86:48-249. https://doi.org/10.1093/oxfordjournals.jhere d.a111573

Reed DH, Frankham R (2003) Correlation between fitness and genetic diversity. Conserv Biol 17:230-237. https://doi.org/1 0.1046/j.1523-1739.2003.01236.x

Reid JM, Arcese P, Keller LF et al (2007) Inbreeding effects on immune response in free-living song sparrows (Melospiza melodia). Proc R Soc London B Biol Sci 274:697-706. https ://doi.org/10.1098/rspb.2006.0092

Richardson DS, Jury FL, Dawson DA et al (2000) Fifty Seychelles warbler (Acrocephalus sechellensis) microsatellite loci polymorphic in Sylviidae species and their cross-species amplification in other passerine birds. Mol Ecol 9:2225-2230. https:// doi.org/10.1046/j.1365-294X.2000.105338.x

Rousset F (2008) genepop'007: a complete re-implementation of the genepop software for Windows and Linux. Mol Ecol Resour 8:103-106. https://doi.org/10.1111/j.1471-8286.2007.01931.x

Rowe G, Beebee TJC, Burke T (1999) Microsatellite heterozygosity, fitness and demography in natterjack toads Bufo calamita. Anim Conserv 2:85-92. https://doi.org/10.1017/S136794309 9000402
Salaberria C, Muriel J, De Luna MÍ et al (2013) The PHA test as an indicator of phagocytic activity in a passerine bird. PLoS ONE 8:e84108. https://doi.org/10.1371/journal.pone.0084108

Salewski V, Canales-Delgadillo J, Flade M et al (2012) Eleven new microsatellite loci in the globally threatened Aquatic Warbler (Acrocephalus paludicola). Conserv Genet Resour 4:279-282. https://doi.org/10.1007/s12686-011-9524-2

Sambrook J, Russell DW (2001) Molecular cloning: a laboratory manual, 3rd edn. Cold Spring Harbor, New York

Sameer AS, Rehman S, Banday MZ et al (2009) Comparison of the different methods of DNA extraction from snap-frozen tumor tissues : our experience. Int J Biotechnol Biochem 5:43-50

Seddon N, Amos W, Mulder RA, Tobias JA (2004) Male heterozygosity predicts territory size, song structure and reproductive success in a cooperatively breeding bird. Proc R Soc B Biol Sci 271:1823-1829. https://doi.org/10.1098/rspb.2004.2805

Sehgal RNM (2015) Manifold habitat effects on the prevalence and diversity of avian blood parasites. Int J Parasitol Parasites Wildl 4:421-430. https://doi.org/10.1016/j.jpppaw.2015.09.001

Sehgal RNM, Jones HI, Smith TB (2001) Host specificity and incidence of Trypanosoma in some African rainforest birds: a molecular approach. Mol Ecol 10:2319-2327. https://doi.org/10.1046/ j.1365-294X.2001.01339.x

Shurulinkov P, Chakarov N, Daskalova G (2012) Blood parasites, body condition, and wing length in two subspecies of yellow wagtail (Motacilla flava) during migration. Parasitol Res 110:20432051. https://doi.org/10.1007/s00436-011-2733-5

Slate J, Kruuk LEB, Marshall TC et al (2000) Inbreeding depression influences lifetime breeding success in a wild population of red deer (Cervus elaphus). Proc R Soc Lond B Biol Sci 267:16571662. https://doi.org/10.1098/rspb.2000.1192

Slate J, David P, Dodds KG et al (2004) Understanding the relationship between the inbreeding coefficient and multilocus heterozygosity: theoretical expectations and empirical data. Heredity (Edinb) 93:255-265. https://doi.org/10.1038/sj.hdy.6800485

Stoffel MA, Esser M, Kardos M et al (2016) inbreedR: an R package for the analysis of inbreeding based on genetic markers. Methods Ecol Evol 7:1331-1339. https://doi. org/10.1111/2041-210X.12588

Stone WB, Weber BL, Parks FJ (1971) Morbidity and mortality of birds due to avian malaria. N Y Fish Game J 18:62-63

Svensson L (1992) Identification guide to European passerines, 4th edn. British Trust for Ornithology, Norfolk

Szulkin M, Bierne N, David P (2010) Heterozygosity-fitness correlations: a time for reappraisal. Evolution (N Y) 64:1202-1217. https://doi.org/10.1111/j.1558-5646.2010.00966.x

Taylor SS, Sardell RJ, Reid JM et al (2010) Inbreeding coefficient and heterozygosity-fitness correlations in unhatched and hatched song sparrow nestmates. Mol Ecol 19:4454-4461. https://doi. org/10.1111/j.1365-294X.2010.04824.x

Townsend AK, Clark AB, McGowan KJ et al (2009) Disease-mediated inbreeding depression in a large, open population of cooperative crows. Proc R Soc B Biol Sci 276:2057-2064. https://doi. org/10.1098/rspb.2008.1852

Townsend AK, Taff CC, Wheeler SS et al (2018a) Low heterozygosity is associated with vector-borne disease in crows. Ecosphere 9:e02407. https://doi.org/10.1002/ecs2.2407

Townsend AK, Wheeler SS, Freund D et al (2018b) Links between blood parasites, blood chemistry, and the survival of nestling American crows. Ecol Evol 8:8779-8790. https://doi. org/10.1002/ece 3.4287

Valkiūnas G (2005) Avian malaria parasites and other Haemosporidia. CRC Press, Boca Raton

Vallender R, Bull RD, Moulton LL, Robertson RJ (2012) Blood parasite infection and heterozygosity in pure and genetic-hybrid 
Golden-Winged Warblers (Vermivora chrysoptera) across Canada. Auk 129:716-724

Van Oosterhout C, Weetman D, Hutchinson WF (2006) Estimation and adjustment of microsatellite null alleles in nonequilibrium populations. Mol Ecol Notes 6:255-256. https://doi.org/10.111 1/j.1471-8286.2005.01082.x

Vangestel C, Mergeay J, Dawson DA et al (2011) Developmental stability covaries with Genome-Wide and Single-Locus heterozygosity in house sparrows. PLoS ONE 6:e21569. https://doi.org/10.1371/ journal.pone.0021569

Vinkler M, Bainová H, Albrecht T (2010) Functional analysis of the skin-swelling response to phytohaemagglutinin. Funct Ecol 24:1081-1086. https://doi.org/10.1111/j.1365-2435.2010.01711.x
White KL, Eason DK, Jamieson IG, Robertson BC (2015) Evidence of inbreeding depression in the critically endangered parrot, the kakapo. Anim Conserv 18:341-347. https://doi.org/10.1111/ acv. 12177

Zídková L, Cepicka I, Szabová J, Svobodová M (2012) Biodiversity of avian trypanosomes. Infect Genet Evol 12:102-112. https://doi. org/10.1016/j.meegid.2011.10.022

Publisher's Note Springer Nature remains neutral with regard to jurisdictional claims in published maps and institutional affiliations. 